\title{
THE EFFECT OF OPHIOCEPHALUS STRIATUS EXTRACT ON SERUM ADIPONECTIN LEVEL OF CANCER CACHEXIA PATIENTS
}

\section{Anna Puteri Gozali}

\section{Savita Handayani*}

\section{Dairion Gatot}

Departement of Internal Medicine, Faculty of Medicine, Universitas Sumatera Utara/Haji Adam Malik General Hospital Medan, Indonesia

Hematology-Oncology Division, Departement of Internal Medicine, Faculty of Medicine, Universitas Sumatera Utara/ Haji Adam Malik General Hospital Medan, Indonesia *Corresponding Author

Hematology-Oncology Division, Departement of Internal Medicine, Faculty of Medicine, Universitas Sumatera Utara/ Haji Adam Malik General Hospital Medan, Indonesia

\section{ABSTRACT}

One of the most common manifestations of advanced cancer is the development of metabolic symptoms called cancer cachexia. Adiponectin plays a role in increasing insulin sensitivity, anti-inflammation, antiatherogenic, proapoptotic, and anti-proliferative. Ophiocephalus striatus or snakehead fish is a potential source of albumin. This study aims to determine the effects of Ophiocephalus striatus extract on serum adiponectin levels of cancer cachexia patients. This study was an open label clinical trial with the design of one group pretest posttest. The study was conducted on January-June 2019 at Haji Adam Malik Hospital in Medan with the approval of the USU FK Research Ethics Commission. Data were analyzed using the SPPS program where $\mathrm{p}<0.05$ was considered significant. The results of this study showed there were significant differences in the serum adiponectin levels of the subjects before and after administration of Ophiocephalus striatus extract for two weeks. The increase in serum albumin levels of cancer cachexia patients was obtained after administration of $5000 \mathrm{mg}$ Ophiocephalus striatusextract twice a day for two weeks.

\section{KEYWORDS : adiponectin, cancer cachexia, Ophiocephalus striatus}

\section{INTRODUCTION}

One of the most common manifestations of advanced cancer is the development of metabolic symptoms called cancer cachexia. Cancer cachexia is often referred to cancer anorexia-cachexia syndrome (CACS) because it often shows symptoms of anorexia accompanied by symptoms of cachexia in cancer patients. ${ }^{1}$ In 2011, an international consensus defined cancer cachexia as: "a multifactorial syndrome characterized by an ongoing loss of skeletal muscle with or without loss of fat mass that cannot be completely reversed by conventional nutritional support and leads to progressive functional disorders. ${ }^{2}$ The main clinical features of cancer cachexia are unintentional weight loss accompanied by anorexia, systemic inflammation, insulin resistance, and increase resting energy expenditure (REE). ${ }^{2}$

Previous studies have shown that half of all cancer patients lose weight and one third lose more than $5 \%$ of body weight. Cachexia accounts for about $20 \%$ of deaths from cancer. ${ }^{3}$ Cancer cachexia negatively affects quality of life, response to chemotherapy, and life expectancy. ${ }^{4,5}$

Adiponectin is a protein, which is most secreted by adipose tissue. Adiponectin plays a role in increasing insulin sensitivity, anti-inflammation, anti-atherogenic, proapoptotic, and anti-proliferative. Adiponectin levels are inversely proportional to the risk of diabetes, coronary heart disease, and some malignancies. Many cancer cell lines express adiponectin receptors, and adiponectin in vitro limits cell proliferation and induces apoptosis. Recent in vitro studies show properties that limit the growth and antiangiogenic growth of adiponectin. ${ }^{6}$

Ophiocephalus striatus or snakehead fish is a potential source of albumin. Previous studies reported that snakehead fish extract was in fact able to maintain the albumin value of hospitalized patients and accelerate the healing process for patients. ${ }^{7,8}$ This study aims to determine the effects of Ophiocephalus striatus extract on serum adiponectin levels of cancer cachexia patients.

\section{METHODS}

This study was an open label clinical trial designed with one group pretest posttest. This study was conducted at Haji Adam Malik General Hospital Medan from January 2019 to June 2019 with the approval from the Research Ethics Commission of Faculty of Medicine of Universitas Sumatera Utara. The informed consent was obtained from subjects who were willing to participate in this study.

Patients who have met the criteria as the subjects were given the extract of Ophiocephalus striatus for 2 weeks. Inclusion criteria in this study were: patients who have been diagnosed with cancer, age $\geq 18$ years, patients who were willing to be the subject, patients who met the criteria of cachexia. ${ }^{2}$ The exclusion criteria in this study were: pregnancy, GFR $<15 \mathrm{ml} / \mathrm{min} / 1.73 \mathrm{~m}^{2}$, proteinuria $\geq+3$, severe systemic disease: lung infection, sepsis, history of other chronic diseases: diabetes mellitus, coronary heart disease, stroke, thyroid dysfunction. The Ophiocephalus striatus extracts used in this study was manufacturer sachets containing $5000 \mathrm{mg}$ Ophiocephalus striatus each sachet. The extract was registered by national food and drug agency. All subjects were given the extract twice a day for two weeks with monitoring of medication compliance. On the $15^{\text {th }}$ day, blood samples were collected by the laboratory assistant for complete blood count, liver and kidney function, and adiponectin serum levels.

\section{RESULT}

This study was attended by 30 cancer cachexia patients. The basic characteristic of the subjects was described in table 1 . The mean age of the subjects was $52 \pm 17$ years. The mean body mass index (BMI) was $17.14 \pm 1.66 \mathrm{~kg} / \mathrm{m}^{2}$. Median adiponectin levels were 5.51 (1.30-22.2) $\mathrm{ng} / \mathrm{mL}$. The mean albumin level were $2.46 \pm 0.46 \mathrm{gr} / \mathrm{dL}$.

Table-1 Basic Characteristic Of The Subjects

\begin{tabular}{|l|l|l|}
\hline Characteristic & $\mathbf{n}=\mathbf{3 0}$ & $\%$ \\
\hline Gender & & \\
\hline Male & 20 & 66.7 \\
\hline
\end{tabular}




\begin{tabular}{|l|l|l|}
\hline Female & 10 & 33.3 \\
\hline Age (years) ${ }^{\alpha}$ & $52 \pm 17^{\alpha}$ & \\
\hline Anthropometry & & \\
\hline Weight $(\mathrm{kg})^{\alpha}$ & $45.4 \pm 5.8$ & \\
\hline Height $(\mathrm{cm})^{\alpha}$ & $162.7 \pm 6.0$ & \\
\hline BMI $\left(\mathrm{kg} / \mathrm{m}^{2}\right)^{\alpha}$ & $17.14 \pm 1.66$ & \\
\hline Upper arm circumference $\left.(\mathrm{cm})^{\mathrm{b}}\right)$ & $26.4(22.3-27.5)$ & \\
\hline Cancer type & & \\
\hline GIT & 14 & 46.7 \\
\hline Lungs & 6 & 20 \\
\hline Nasopharyngeal carcinoma & 4 & 13.3 \\
\hline NHL & 2 & 6.7 \\
\hline Ovarium & 2 & 6.7 \\
\hline Thyroid & 1 & 3.3 \\
\hline Breast & 1 & 3.3 \\
\hline Chemotherapy status & & \\
\hline Chemotherapy & 5 & 16.7 \\
\hline Non-chemotherapy & 25 & 83.3 \\
\hline
\end{tabular}

inpaired t-test

\section{DISCUSSION}

The scientific development has revealed the fact that Ophiocephalus striatus has an excellent nutritional effect for health. The extract consists of high protein content (especially, albumin and essential amino acids), fats (especially essential fatty acids), minerals (especially Zinc), and some vitamins that are very good for health. ${ }^{9}$ Ophiocephalus striatus has been known contain higher protein than other fish species. The albumin levels can reach $6.22 \%{ }^{10}$

This study showed an increase in weight and BMI of cancer cachexia patients although statistically, the increase in BMI and weight was not significant. Previous studies regarding the use of Ophiocephalus striatus extract on HIV-AIDS and COPD patients with cachexia showed significant body weight improvement after administration of this extract. ${ }^{11,12}$ The insignifcant increase of body weight in this study might be due to short duration of study. The better results on weight gain and BMI might be achieved if the time of administration of Ophiocephalus striatus extract were longer.

Table 2 showed a comparison of clinical and laboratory parameters before and after therapy. The results showed that there were significant differences in the serum albumin and adiponectin levels of the subjects before and after receiving the extract of Ophiocephalus striatus $(p<0.05)$.

Table - 2 Clinical And Laboratory Parameters Before And After Administration Of Ophiocephalus Striatus Extract

\begin{tabular}{|l|l|l|c|}
\hline \multicolumn{1}{|c|}{ Parameter } & \multicolumn{1}{|c|}{$\begin{array}{c}\text { Before } \\
(\mathbf{n = 3 0})\end{array}$} & \multicolumn{1}{|c|}{$\begin{array}{c}\text { After } \\
(\mathbf{n}=30)\end{array}$} & P \\
\hline Weight $(\mathrm{kg})$ & $45,4 \pm 5.8$ & $45.5 \pm 5.7$ & 0.629 \\
\hline BMI $^{\alpha}\left(\mathrm{kg} / \mathrm{m}^{2}\right)$ & $17.14 \pm 1.66$ & $17.18 \pm 1.63$ & 0.598 \\
\hline $\begin{array}{l}\text { Upper arm } \\
\text { circumference }^{\mathrm{b}}(\mathrm{cm})\end{array}$ & $\begin{array}{l}26.4 \\
(22.3-27.5)\end{array}$ & $\begin{array}{l}26.5 \\
(22.3-27.5)\end{array}$ & 0.060 \\
\hline Haemoglobin $^{\alpha}(\mathrm{gr} / \mathrm{dL})$ & $9.5 \pm 1.5$ & $9.9 \pm 1.7$ & 0.177 \\
\hline Hematocrit $^{\alpha}(\%)$ & $28.3 \pm 4.6$ & $30.0 \pm 5.3$ & 0.127 \\
\hline WBC $\left(\mathrm{sel} / \mathrm{mm}^{3}\right)$ & 10320 & $\begin{array}{l}8760 \\
(2680-31890)\end{array}$ & 0.820 \\
\hline Platelet $^{\mathrm{b}}\left(\mathrm{sel} / \mathrm{mm}^{3}\right)$ & $327(24-757)$ & $342(25-523)$ & 0.406 \\
\hline Ureum $^{\mathrm{b}}(\mathrm{mg} / \mathrm{dL})$ & $32(6-133)$ & $29(13-133)$ & 0.366 \\
\hline Creatinine $^{\mathrm{b}}(\mathrm{mg} / \mathrm{dL})$ & $\begin{array}{l}0.79 \\
(0.35-3.11)\end{array}$ & $\begin{array}{l}0.70 \\
(0.32-2.61)\end{array}$ & 0.073 \\
\hline AST $^{\mathrm{b}}(\mathrm{u} / \mathrm{L})$ & $26(13-175)$ & $24(10-64)$ & 0.490 \\
\hline ALP $^{\mathrm{b}}(\mathrm{u} / \mathrm{L})$ & $20(6-83)$ & $22(6-106)$ & 0.147 \\
\hline Albumin $^{\alpha}(\mathrm{gr} / \mathrm{dL})$ & $2.46 \pm 0.46$ & $2.92 \pm 0.56$ & $<0.001^{*}$ \\
\hline CRP $^{\mathrm{b}}(\mathrm{mg} / \mathrm{L})$ & $1.4(0.7-2.8)$ & $1.4(0.7-2.8)$ & 0.347 \\
\hline Adiponectin $^{\mathrm{b}}(\mathrm{ng} / \mathrm{mL})$ & $5.51(1.30-22.2)$ & $9.33(1.25-35.7)$ & $0.01^{*}$ \\
\hline
\end{tabular}

${ }^{a}$ normal distribution; mean $\pm \mathrm{SD}$; paired t-test

${ }^{\mathrm{b}}$ abnormal distribution; median (minimum-maximum); Wilcoxon

Table 3 showed differences in albumin and adiponectin levels before and after therapy in the chemotherapy and nonchemotherapy groups. No significant differences were found between chemotherapy and non-chemotherapy groups ( $\mathrm{p}=$ 0.403 and 0.999 ).

Table - 3 Difference Of Albumin And Adiponectin Level Based On Chemotherapy Category

\begin{tabular}{|l|c|c|c|c|}
\hline Parameter & Before & After & $\Delta$ & P \\
\hline Albumin (gr/dL) & & & & \\
\hline Chemotherapy & 3.02 & 3.60 & 0.58 & 0.403 \\
\hline Non-chemoterapy & 2.36 & 2.76 & 0.43 & \\
\hline Adiponectin (ng/mL) & & & & \\
\hline Chemotherapy & 5.94 & 11.14 & 5.2 & 0.999 \\
\hline Non-chemoterapy & 7.12 & 12.32 & 5.2 & \\
\hline
\end{tabular}

This study showed an increase in serum albumin levels of cancer cachexia patients after administration of Ophiocephalus striatus extract at a dose of $5000 \mathrm{mg}$ twice a day for two weeks. Previous studies have shown an increase in serum albumin after administration of snakehead fish extract. ${ }^{11-13}$ Ophiocephalus striatus extracts were proven to be a food supplement that can increase serum albumin levels in patients with hypoalbuminemia.

Anti-inflammation effect of adiponectin may be mediated by various potential pathways including the capacity to suppress TNF synthesis and the ability to induce the production of antiinflammatory cytokines such as IL-10 and IL-l receptor antagonists. Adiponectin plays an important role in inhibiting the activation of macrophages. Adiponectin inhibits transactivation of NF- B and induces anti-inflammatory IL-10 through ERKl/2 and AKT by mediation of AdipoRl. ${ }^{14}$ This antiinflammatory effect has been proved in osteoarthritis patients. ${ }^{15}$ There was no significant differences between serum CRP levels before and after administration of Ophiocephalus striatus extract. It might be concluded that extract of Ophiocephalus striatus had anti-inflammatory effects through the leptin and adiponectin pathways.

There was no significant difference in complete blood count, liver and kidney function in the subjects before and after administration of Ophiocephalus striatus extract. No side effect was observed on the subject during the study period. This has been proven that the administration of snakehead fish extract for two weeks did not cause side effects.

The increase of serum albumin levels in the chemotherapy group was higher than in the non-chemotherapy group. Although statistically this difference was not significant, but based on the results, we can conclude that administration of Ophiocephalus striatus extract could help clinical improvement in cancer patients undergoing chemotherapy. There were some limitations of the study. The short duration in the study led to non-optimal results in both benefits and side effects. Longer duration is needed to get more exact results from the effects of Ophiocephalus striatus extract.

\section{CONCLUSIONS}

The increases of serum adiponectin and albumin levels in cancer cachexia patients were obtained after administration of Ophiocephalus striatus extract $5000 \mathrm{mg}$ twice a day for two weeks. 


\section{REFERENCES:}

[1] Evans WJ, Morley JE, Argilés J, Bales C, Baracos V, Guttridge D, et al. Cachexia: Anew definition. Clinical Nutrition. 2008;27(6):793-9.

[2] Fearon K, Strasser F, Anker SD, Bosaeus I, Bruera E, Fainsinger RL et al. Definition and classification of cancer cachexia: An international consensus. The Lancet Oncology. 2011 May;12(5):489-495. Available from, doi: $10.1016 / \mathrm{S} 1470-2045(10) 70218-7$

[3] Argiles, J.M., Busquets, S., Stemmler, B., and Lopez-Soriano, F.J. (2014). Cancer cachexia: understanding the molecular basis. Nat Rev Cancer 14, 754-762.

[4] Anker SD, Coats AJ. Cardiac cachexia: a syndrome with impaired survival and immune and neuroendocrine activation. Chest. 1999;115:836-847.

[5] MacDonald N, Easson AM, Mazurak VC, et al. Understanding and managing cancer cachexia. J Am Coll Surg. 2003;197:143-161.

[6] Katira A, Peng H. Tan. Evolving role of adiponectin in cancer. Cancer Biol Med 2016; 13(1):101-119. doi: 10.28092/j.issn.2095-3941.2015.0092.

[7] Fatmawati. (2014). Tepung Ikan Gabus Sebagai Sumber Protein (Food Suplement). Fakultas Pertanian. Universitas " $45^{\prime \prime}$ Makassar. Junal Bionature volume 15, No 1 April 2014 hal 54-60.

[8] Taslim NA., Penyuluhan Gizi, Pemberian Soy Protein Dan Perbaikan Status Gizi Penderita Tuberkulosis di Makassar. Jurnal Medika Nusantara. Vol. 25. No. 2. www.med.unhas.ac.id. 2004

[9] A, Mustafa, M. Aris Widodo, Yohanes Kristianto. 2012. Albumin And Zinc Content Of Snakehead Fish (Channa striata) Extract And Its Role In Health. IEESE International Journal of Science and Technology (IJSTE), Vol. 1 No. 2, June 2012,1-8.

[10]Carvallo, 1998. Studi profil asam amino, albutnin dan mineral Zn pada ikan gabus dan Tomang Skripsi, Unibraw. Malang.

[11] Salma, Wa Ode.. Pengaruh Pemberian Kapsul Ikan Gabus Terhadap Kadar Albumin Dan Status Gizi Pada Pasien ODHA (Orang Dengan HIV/AIDS) Di RSU Dr. Wahidin Sudirohusodo Makassar. Program Pascasarjana Universitas Hasanuddin. 2007.

[12] Widiasari, Komang Sri Rahayu, Susanthy Djajalaksana, Harun Al Rasyid. Pengaruh Pemberian Ekstrak Ikan Gabus Terhadap Kadar Leptin, Adiponektin dan Skor COPD Assessment Test pada Pasien PPOK Stabil yang Mengalami Muscle Wasting. J Respir Indo Vol. 38 No. 3 Juli 2018.

[13] Hidayanty, Healthy. Pengaruh Pemberian Kapsul Konsentrat Ikan Gabus Pada Pasien Pasca Bedah di RSU DR. Wahidin Sudirohusodo Makassar. Program Pascasarjana Universitas Hasanuddin. 2007.

[14] Bianco A, Mazzarella G, Turchiarelli V, Nigro E, Corbi G, Scudiero O, et al. 2013. Review: Adiponectin: An Attractive Marker for Metabolic Disorders in Chronic Obstructive Pulmonary Disease (COPD). Nutrients. 5: 4115-41

[15] Michelle NYT, Shanthi G \& Logman MY. Effect of orally administered Channa striatus extract against experimentally induced osteoarthritis in rabbits. Int J Appl Res Vet Med. 2000; 2: 171-175 